\title{
ECONOMIC ANALYSIS OF FARM-GATE PLANTAIN MARKETING IN ABIA STATE, NIGERIA
}

\author{
AGWU, N.M.; C. C. EKE, I. N. NWACHUKWU AND I. V.OGBU \\ College of Agribusiness and Financial Management \\ Michael Okpara University of Agriculture, \\ Umudike, P.M.B. 7267, Umuahia, Abia State. \\ E-mail: namak71@yahoo.com
}

\begin{abstract}
This paper is on the economic analysis of farm gate plantain marketing in Abia state, Nigeria. The study adopted a multi-stage random sampling technique. However, three local government areas of Bende, Ikwuano and Isiukwuato were purposively selected based on the fact that they are the major producers of plantain in the state. Four communities were then selected from the 3 LGAs. This gave a total of 12 communities. The next stage was the selection of 5 farm families from each of the 12 communities, giving a total of 60 respondents. For the selection of the middlemen and consumers, three urban local government areas of Umuahia North, Umuahia South and Aba North were selected purposively. 10 wholesalers, retailers and consumers were also randomly selected from these urban areas. This gave a total of 90 respondents. In all, 150 respondents were used for the study. Data were obtained by the use of questionnaire and were later analyzed using marketing margin and multiple regression. The result of the analysis showed that the margin for retailers were more than those of the producers and wholesalers. Output price was found to be positive and significant in determining profitability. Labour and fertilizer had negative relationship with profitability. It was recommended that costs of inputs be reduced as well as making information accessible to the producers.
\end{abstract}

Key words: Farm gate, Marketing margin, Plantain, Profitability, Retailers , Wholesalers

\section{INTRODUCTION}

Plantain is one of the major food crops in the humid and sub-humid parts of Africa and is a major source of energy for millions of people in these regions (Ogazi, 1996). In Nigeria, plantain has become a staple food, just like garri, yam and cassava (Arene, 1995). It commands a prime position among other fruits. Plantain as a source of food energy and carbohydrate provides a substantial amount of recommended nutrients uptake of potassium and pro vitamin A (carotene) (FAO, 2003). Iron content of plantain is 100 percent utilizable for human consumption unlike other foods. In the past, Nigeria had paid more attention to the production and marketing of cash crops (FAO, 2004).

The reason was that the colonial masters were more interested in the crop that supplied raw material to their home industries. This accounted for the creation of various marketing boards for different export crops. However in recent times, considerable interest has been shown by agricultural and development economists, geographers and other social scientists on internal exchange in many developing countries of the world. This increased interest comes from a re-evaluation of the role of marketing and distribution in the development process. According to Kohl and Downey (1972), production and marketing are interrelated that any defects in one would readily affect the performance of the other. Every effort should therefore be made to ensure that both farm and industrial products are distributed to the ultimate consumers. Smith (1990) had opined that consumption is the sole end and purpose of all production and the interest of producer is to be attended to, only in so far as it may be necessary for promoting that of the consumers. The marketing of any 
commodity is a specialized technique. In the case of agriculture and particularly plantain and its products, the marketing aspect is even more important and demands a proper organization, considering the increasing demand of the produce (IKeme, 1990).

Olukosi and Isitor (1990) remarked that within the marketing system that price allocation of resources, income distribution and capital formation are determined. CARE (2004), described marketing as a machine that directs production along the line most suited to the consumer requirement. Thus, production is limited by the extent of marketing. Ikisan (2004), highlighted the contributions of agriculture and food marketing towards an attempt to improve rural income in developing countries. According to him, the inequality of income between the rural and urban areas draws people away from agricultural production and places greater stress upon towns and cites. However, inconsistency in supply due to seasonal variations of production, expensive and inefficient transportation system, lack of storage facilities have tended to exacerbate the problem associated with plantain marketing (Arene, 2003). Despite these problems farmers and marketers alike still remain in business (Ikisan, 2004). Hence, this study to:

(i) examine the marketing marginal

(ii) estimate the profitability of farm gate, wholesale and retail enterprise in the study area.

(iii) analyze the factors that affect the profitability of farm gate plantain enterprise in the state and

Beside this, the study attempts to focus more on producer profits by determining the affect of producer and farm input prices on the profitability on farm gate plantain farmers in Abia state. This is with a view to identifying the variable factors that influence the profitability of farm gate plantain farmers, being the primary suppliers of the product.

\section{METHODOLOGY}

The study was carried out in Abia state of Nigeria. Abia state lies between longitude $04^{0} 45^{\prime}$ and $06^{\circ} 17^{\prime}$ North and latitude $07^{\circ} 00^{\prime}$ and $08^{\circ} 10^{\prime}$ East. It is situated in the SouthEastern part of Nigeria and is bounded by Imo State on the West, Ebonyi and Enugu States on the North, Cross Rivers and Akwa Ibom States on the East and River State on the South. The State has a population of about 2, 833, 99 million persons (NPC, 2007). Administratively the State has 17 local government areas. The study made use of a multi-stage sampling technique. The first stage was the selection of 3 local government areas which are known to be large producers of plantain. Secondly, 4 communities from the 3 local government areas were chosen, making up 12 communities, 5 farm families were selected from the 12 communities, bringing the total number to 60 respondents. In the selection of middle men and consumers, 3 urban areas of the state viz Umuahia North, Umuahia South and Aba North were selected randomly. 10 middlemen and retailers were then selected from these urban centres giving a total of 30 wholesalers and 30 retailers. 10 consumers were also selected from the 3 centres totaling 30 consumers. In all, 150 respondents were used for the study. The study made use of mainly data collected from these respondents through structured questionnaire. The models used in the analysis were specified as follows:

$\mathrm{Mm}=\mathrm{Rp}-\mathrm{Mc}$.

Where

$\mathrm{Mm}=$ marketing margin

$\mathrm{Rp}=$ Ratail price

Mc $=$ marketing cost.

This formular applies to producers, wholesalers and retailers margin. This formular has been used by Osuji (1980).

Profit function is specified thus: 


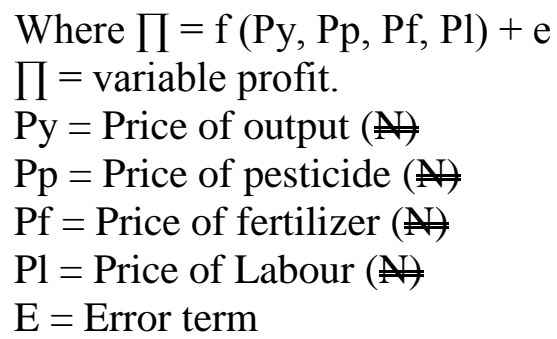

This was adapted from Ike and Chukwuji (2005).

RESULTS AND DISCUSSION

Socio-Economic Characteristics of the Respondents

Table1. Distribution of Respondents According to Sex

\begin{tabular}{llllllllc}
\hline Sex & \multicolumn{2}{c}{ Producer } & \multicolumn{2}{c}{ Wholesalers } & \multicolumn{2}{c}{ Retailers } & \multicolumn{2}{c}{ Consumers } \\
& No & \% & No & \% & No & \% & No & \% \\
\hline Male & 42 & 70 & 12 & 40 & 13 & 43 & 18 & 60 \\
Female & 18 & 30 & 18 & 60 & 17 & 57 & 12 & 40 \\
\hline Total & $\mathbf{6 0}$ & $\mathbf{1 0 0}$ & $\mathbf{3 0}$ & $\mathbf{1 0 0}$ & $\mathbf{3 0}$ & $\mathbf{1 0 0}$ & $\mathbf{3 0}$ & $\mathbf{1 0 0}$ \\
\hline
\end{tabular}

Source: Field Survey, 2008.

As shown in table 1 above, majority of the producers and consumers are males in the study area, whereas majority of the wholesalers and retailers are females. The implication of this result is that women are mainly involved in the marketing activities of plantain in the study area. This result is also in line with earlier studies of Eluagu and Unanma (1980); MorrisHughes (1994) and Ekumankama (2000) in respect to women's involvement in the marketing of agricultural produce.

Table 2: Distribution of Respondents According to Age

\begin{tabular}{lcccccc}
\hline Age Range in Years & \multicolumn{2}{c}{ Producers } & \multicolumn{3}{c}{ Wholesalers } & \multicolumn{2}{c}{ Retailers } \\
& No & $\%$ & No & $\%$ & No & $\%$ \\
\hline $30-39$ & - & - & 18 & 60 & 19 & 63 \\
$40-49$ & 32 & 52 & 12 & 40 & 11 & 37 \\
$50-69$ & 28 & 47 & - & - & - & \\
70 and above & - & - & - & - & - & \\
\hline Total & $\mathbf{6 0}$ & $\mathbf{1 0 0}$ & $\mathbf{3 0}$ & $\mathbf{1 0 0}$ & $\mathbf{3 0}$ & $\mathbf{1 0 0}$ \\
\hline
\end{tabular}

Source: Field Survey, 2008

From the table 2 above, it is seen that majority of the producers (farmers) were within the age range of 40-49 years, while majority of the wholesalers and retailers were within the age range of 30-39 years. Only about 40 and 37 percent were within the range of 40-49 years for the wholesalers and retailers respectively.

Table 3: Distribution of the Respondents According to Household size

\begin{tabular}{lcccccccc}
\hline Household size & \multicolumn{2}{l}{ Producers } & \multicolumn{2}{c}{ Wholesalers } & \multicolumn{2}{c}{ Retailers } & \multicolumn{2}{c}{ Consumers } \\
No. of persons & No & \% & No & \% & No & \% & No & \% \\
\hline $1-5$ & 50 & 83 & 15 & 50 & 20 & 67 & 20 & 67 \\
$6-10$ & 10 & 17 & 15 & 50 & 10 & 33 & 10 & 33 \\
$11-15$ & - & - & - & - & - & - & - & - \\
\hline Total & $\mathbf{6 0}$ & $\mathbf{1 0 0}$ & $\mathbf{3 0}$ & $\mathbf{1 0 0}$ & $\mathbf{3 0}$ & $\mathbf{1 0 0}$ & $\mathbf{3 0}$ & $\mathbf{1 0 0}$ \\
\hline
\end{tabular}

Source: Field Survey, 2008. 
As revealed in Table 3, majority of the households have between 1-5 persons in their households; producers, wholesalers, retailers and consumers inclusive. Non-of the respondents had more than 10 persons in their households.

Table 4: Educational Attainment of the Respondents

\begin{tabular}{llllllllr}
\hline Years Spent & \multicolumn{2}{c}{ Producers } & \multicolumn{3}{c}{ Wholesalers } & \multicolumn{2}{c}{ Retailers } & \multicolumn{2}{c}{ Consumers } \\
In school & No & $\%$ & No & $\%$ & No & $\%$ & No & $\%$ \\
\hline Zero & - & - & - & - & - & - & - & - \\
$6-10$ & 26 & 43 & 17 & 57 & 17 & 57 & 7 & 23 \\
$11-15$ & 25 & 42 & 11 & 37 & 11 & 37 & 8 & 27 \\
13 years and above & 9 & 15 & 2 & 06 & 2 & 2 & 15 & 50 \\
\hline Total & 60 & 100 & 30 & 100 & 30 & 100 & 30 & 100 \\
\hline
\end{tabular}

Source; Field Survey, 2008.

From table 4 above, it could be seen that majority of the producers, wholesalers and retailers in the study area had spent 6 years in the school; whereas majority of the consumers had spent 13 years or more in school.

1-6 years connotes primary school education; 7-12 secondary education while 13 years above connotes tertiary education.

\section{Marketing margins}

a. Producers Margin

(i) Producers Revenue

Average production 280 bunches @ $\$ 400.00 /$ bunch

Total Revenue $=\$ 112,000.00$

(ii) Producers cost

Cost of suckers - $\quad \$ 20,500.00$

Cost of Fertilizer - $\$ 9,850$

Cost of labour - $\quad \$ 16,000.00$

Transportation - $\quad \$ 2,800.00$

Total cost $\quad-\quad \$ 61,150.00$

Producers margin PR-PC

Where: $\mathrm{PR}=$ Producers Revenue

$\mathrm{Pc}=$ Producers cost

$¥(112,000.00-61,150.00)$

\# $50,850.00$

(i) Wholesaler Revenue

Average sales of 280 bunches @ 550.00/bunch

ii. Wholesalers cost

$\begin{array}{ll}\text { Purchase price } & -\$ 112,000.00 \\ \text { Transportation } & -\$ 3000.00 \\ \text { Loading } & -\$ 1500.00 \\ \text { Storage } & -\$ 1200.00 \\ \text { Total } & -\$ 117,700.00\end{array}$

Wholesalers margin $(\mathrm{Wm})=\mathrm{WR}-\mathrm{WC}$

Where: $\mathrm{WR}=$ Wholesalers Revenue

$\mathrm{WC}=$ Wholesalers cost

(154,000.00-117,700.00)

$¥ 36,300.00$

c. Retailers Margin 
(i) Retailers Revenue

Average sales of 280 bunches @ 600.00/bunch

Total Revenue - $\$ 240,000.00$

Transportation - 3000.00

Loading $\quad-\quad 1500.00$

Storage $\quad-\$ 2500.00$

Total - $\quad 161.000 .00$

Retailer Margin $(\mathrm{Rm})=\mathrm{RR}-\mathrm{RC}$

Where: $\mathrm{RR}=$ Retailer Revenue

Retailer Cost $\$(24,000.00-161,000.00)$

To calculate the consumers percentage expenditure on one bunch of plantain that goes to middlemen as net margin or profit-

$$
\text { Percentage Profit }=\frac{\prod(\text { Naira }) / \text { bunch }}{\text { RP/bunch }} \times \frac{100}{1}
$$

Where $\Pi=$ Profit

$$
\mathrm{Rp}=\text { Retail price }
$$

$\frac{150+50 \times 100=17.39 \%}{600+550}$

$600+550$

To obtain percentage of consumers spending on one bunch of plantain

Where: $\mathrm{Mc}=$ Marketing cost

$\mathrm{Rp}=$ Retailer Price

$$
\frac{50 \times 100}{600} \quad=8.3 \%
$$

To obtain the farmer's share (FS) as a percentage of the consumer spending on retail price bunch

Rs $=$ average producer price/bunch

Retail Price/bunch

Where Rs $=$ Retail Price

$$
\frac{218.39}{600}=0.36 \%
$$

To calculate the percentage marketing margin that will go to the middlemen as net profit $=$ Net profit = Profit ( ) /bunch $\times 100$

Marketing Margin/bunch

$$
=\frac{150+50 \mathrm{x}}{79000+36300 \quad \frac{100}{1}} \quad=0.17 \%
$$

*Source: All computations are based on Field survey data, 2008.

From the calculations above, it will be seen that the producers margin was $\$ 50,850.00$; wholesalers margin $\$ 36,300.00$ and retailers margin $\$ 79,00.00$. Arising from this, it is seen that retailer's margin are more than those of the producers and wholesalers.

The consumers percentage expenditure per bunch that goes to middlemen is $17.39 \%$, percentage of consumers spending per bunch is given as $8.3 \%$ where as consumer's spending on retail per bunch is $0.36 \%$. However, the percentage marketing margin that goes to middlemen as net profit is $0.17 \%$.

This goes to show the magnitude, in terms of cost, the exploitative tendencies of the middlemen. From the foregoing, it can be seen that the study tried to isolate unnecessary and exploitative costs built into the production cost by the middlemen along the marketing chain. 


\begin{tabular}{|c|c|c|c|c|}
\hline Variable & Linear & Double log & Semi-log & Exponential \\
\hline Constant & $\begin{array}{ll}- & 5896.466 \\
& (269.40)\end{array}$ & $\begin{array}{l}-5.703 \\
(8.135)\end{array}$ & $\begin{array}{l}6.130 \\
(2.246)\end{array}$ & $\begin{array}{l}10.580 \\
(1.288)\end{array}$ \\
\hline $\begin{array}{l}\text { Price of } \\
\text { output (Py) }\end{array}$ & $\begin{array}{l}27.812 \\
(1.950)^{* *}\end{array}$ & $\begin{array}{l}3.032 \\
(2.053)^{* *}\end{array}$ & $\begin{array}{l}29.423 \\
(2.041)^{* *}\end{array}$ & $\begin{array}{l}6.538 \\
(0.365)\end{array}$ \\
\hline $\begin{array}{l}\text { Price of } \\
\text { Pesticides (Pp) }\end{array}$ & $\begin{array}{l}1.788 \\
(1.406)^{*}\end{array}$ & $\begin{array}{l}1.224 \\
(1.097)\end{array}$ & $\begin{array}{l}11.209 \\
(1.030)\end{array}$ & $\begin{array}{l}1.156 \\
(0.830)\end{array}$ \\
\hline $\begin{array}{l}\text { Price of } \\
\text { fertilizer (Pf) } \\
\text { Price of } \\
\text { Labour (PL) } \\
\mathrm{R}^{2} \\
\text { Adjusted } \mathrm{R}^{2} \\
\text { F-ratio }\end{array}$ & $\begin{array}{l}2.868 \\
(0.247) \\
-2.868 \\
(-0.688) \\
.490 \\
.396 \\
5.34 \\
\end{array}$ & $\begin{array}{l}-8.727 \\
(-15.693)^{* * *} \\
-7.6 . \\
(-15.693)^{* * *} \\
.678 \\
.542 \\
7.830\end{array}$ & $\begin{array}{l}7.548 \\
(0.378) \\
12.028 \\
(1.040) \\
.387 \\
.417 \\
4.331 \\
\end{array}$ & $\begin{array}{l}11.190 \\
(2.188)^{* * *} \\
1.420 \\
(6.157)^{* *} \\
.224 \\
.372 \\
4.873\end{array}$ \\
\hline
\end{tabular}

Source: Computations from Field Survey, 2008.

Note: Values in parenthesis are the standard errors.

*** $\quad$ Significant at $1 \%$ level of significance.

** $\quad$ Significance at $5 \%$ level of significance

* $\quad$ Significant at $10 \%$ level of significance.

Four functional forms were tried out in the regression model. The double log was chosen based on some econometric considerations such as number of significant variables, the magnitude of the coefficient of multiple determinations $\left(\mathrm{R}^{2}\right)$ and the F-ratio.

Based on the analysis, the price of output (Py) was significant and positive. This implies that as the price of output increases, the profit accruable to the producers at farm gate increases. This result is strictly in line a prior expectation. If output prices increases, there is every tendency that the profitability will increase. Fertilizer and labour prices were significant and negative at 1 percent level.

This result implies that any 1 percent increase in the price of fertilizer and labour will cause a 1 percent reduction in profitability of farm gate traders. This is obvious given the fact that fertilizer and labour are inputs. Any increase in input costs will affect the profit levels. This finding is in line with Agwu (2009).

\section{CONCLUSION AND RECOMMENDATIONS}

This paper has shown that the marketing margin for retailers is greater than those of wholesalers and farmers (producers) of plantain in the study area. This is greater by $¥ 29$, 000.00 for producers and $\$ 32,700.00$ for wholesalers. The study also revealed that the percentage profit that goes to middlemen is $17.39 \%$ whereas the percentage of consumers spending on one bunch of plantain is $8.35 \%$. The result of the study also revealed that the price of output, price of labour and price of fertilizer were significant and influenced significantly the profit level of the farm gate plantain producers. However, the price of labour and fertilizer had a negative relationship with profitability.

It is recommended that the cost of inputs be reduced and made affordable to farmers. Given the fact that any $1 \%$ increase in cost of inputs reduces farmers profit by $1 \%$, any reduction in the cost of these farm inputs will in no small way boast their profit margin. 
On this basis of the attendant exploitation of the middlemen, it is also recommended that consumer protection outfits of government should assist in regulating prices in the primary markets.

\section{REFERENCES}

Agwu, N. M (2001).Marketing of Women's Agricultural Labour. Paper Presented at the Annual Conference of Nigeria Association of Agricultural Economists (NAAE) at the University of Nigeria, Nsukka. 11-13 June.

Agwu, N.M. (2009).Determinants of Profitability among Plantain Marketers in Abia State, Nigeria. Nigerian Journal of Development Studies.7 (1):49-58.

Arene, C. J (1995). Measurement of Resource Productivity and the Efficiency of Labour-use Among Small Holder Rice Farmers in Rural Nigeria. Modelling Measurements and Control.2.ppl-3.

Arene, C. J. (2003). Introduction to Agricultural Marketing Analysis and Policy. Nsukka Nigeria: Falladu Publishing Company.

CARE (2004). Rice Marketing Survey Report. August 2004.CARSE International Timor. www. Jica.go JPs easttimor/ English/topics/pdpt/report.Pft similar pages. Retrieved Oct.2007.

Ekumankama, O.O (2000). Participation of Rural Women in Livestock Marketing in Ikwuano Area of Abia State, Nigeria. 25 ${ }^{\text {th }}$ Annual NSAP Conference Proceedings March 1923.pp.375-376.

Eluagu, L. S and Unanma, M. N (1980). A Survey of the Role of women in the Marketing of Agricultural commodities in Imo State. A Paper Presented at the $25 \mathrm{~h}$ Annual Conference of the Agricultural Society of Nigeria. Sept.3-6 Owerri.

Food and Agriculture Organization (FAO) (2003) Special Report of FAO on Crop and Food Supply Assessment Mission to Timor Leste.

Food and Agriculture Organization (FAO) (2004) Production Year Book. FAO STAT Data United Nations, Rome.

Ike, P.C and C.O Chukwuji (2005).Efficiency Measurement of Cashew nut Marketing in Enugu State, Nigeria. Journal of Agriculture Food, Environment and Extension 4(1). Pp 46-49.

Ikeme, A. I (1990).The Challenges of Agriculture in National Development. Enugu Optimal

Computer Solutions.

Ikisan (2004). Marketing of Rice, Food Corporation of India (FCI): State Agricultural Marketing Federation (Market Yards): State Co-operative Societies, Wholesale Dealers. www.ikisan com/links/ap rice marketing. Retrieved Oct.28, 2007.

Kohl, R. L and W.D. Downey (1972). Marketing of Agricultural Products $4^{\text {th }}$ Edition. New York.

Morris-Hughes, E. (1994).Gender and Economic Adjustment in Sub-Sahara Africa. Findings of Africa Report Dept.No.9.Washingtom D. C. World Bank.

National Population Commission (NPC) (2007) Details of the Breakdown of the 2006 National Population Census. Schedule II.B 179.

Olukosi, J.O and S.U Isitor (1990).Introduction to Agricultural Marketing and Practice. Principles and Applications. Abuja FCT. Nigeria. G.U Publications.

Smith, L.P (1990).Structural Adjustment, Price Reform and Agricultural Performance in SubSahara Africa. Journal of Agricultural Economics 40.

Ogazi, P.O (1996).Plantain: Production and Processing and Utilization.Okigwe Paman and Associates Limited.

Osuji, O. (1980). Rice Marketing in Abeokuta Local Government Area of Ogun State, Nigeria: A Functional Approach. Nigerian Journal of Marketing Vol.2 pp11245. 